\title{
Knowledge of the context, behavior, and expectations of miners in relation to the tin mining political policies and practices in Bangka Belitung
}

\author{
Pengetahuan konteks, sikap, dan ekspektasi para penambang terhadap \\ politik kebijakan dan praktik penambangan timah di Bangka Belitung
}

\author{
Ibrahim, Dwi Haryadi, \& Nanang Wahyudin \\ Universitas Bangka Belitung \\ Kampus Terpadu Balunijuk, Merawang, Bangka Belitung 33172 \\ E-mail:iim_babel@yahoo.com,dwi_lawangsewu@yahoo.co.id \& nanang_wahyudin@yahoo.com \\ Phone: +6281368957615
}

\begin{abstract}
In the last two decades, tin mining in Bangka Belitung Islands has operated in controversy, between groups who oppose the idea of unconventional mining and those expecting the mining to be carefully performed. This is as well as prioritizing sustainability principles. Amidst the controversy, the unconventional mining methods conducted by local people have been preserved. This writing has observed the miners' perspective of their profession. This study used quantitative methods to explore the miners' knowledge, context, behavior, and expectations of the politics of tin mining policies and its practices. The data analysis used was frequency table and Kendall's Tau-b correlation by applying SPSS version 20 Program. This study found that miners were generally aware that the tin wealth in this region provided great contributions to the economy sector. They also realized that their mining broke the regulation and understood that the benefits they gained were less than that gained by businessmen. The miners' behaviour also showed awareness that mining damages the environment. A behaviour of hesitation was shown in whether they were ready or not to change their profession, the easiness of finding another job, and whether the mining situation that they worked in should be forbidden or firmly dealt with. Nevertheless, the miners hope that recent conditions can be maintained rather than restricted. This study concluded that there were inconsistent political policies at the implementation level, strengthened by the weakness of law culture in society.
\end{abstract}

Keywords: miners; political policy; tin mining

\begin{abstract}
Abstrak
Sejak lebih kurang dua dekade terakhir, penambangan timah di Kepulauan Bangka Belitung berjalan di antara kontroversi antara mereka yang setuju dengan penambangan rakyat yang bersifat inkonvensional dengan mereka yang berharap penambangan dilakukan secara hati-hati dan mengedepankan prinsip keberlanjutan. Di tengah kontroversi itu, penambangan rakyat yang bersifat inkonvensional tetap saja berlangsung. Tulisan ini mengulas pandangan para penambang rakyat terhadap profesi yang mereka geluti. Studi ini menggunakan metode kuantitatif untuk membedah pengetahuan terhadap konteks, sikap, dan ekspektasi para penambang terhadap politik kebijakan penambangan timah dan praktiknya yang berjalan selama ini. Adapun teknik analisis data yang digunakan adalah tabel frekuensi dan hasil korelasi Kendall's Tau-b menggunakan program SPSS versi 20. Studi ini menemukan bahwa secara umum para penambang menyadari timah yang kaya di daerah ini berkontribusi besar terhadap ekonomi. Mereka juga menyadari bahwa penambangan mereka melanggar aturan dan memahami bahwa keuntungan mereka sebenarnya sangat kecil dibandingkan dengan pengusaha. Sikap para penambang pun menunjukkan kesadaran bahwa penambangan mereka meruskan lingkungan. Sikap cenderung ragu-ragu ditunjukkan pada perihal apakah siap beralih profesi, kemudahan mendapatkan pekerjaan lain, dan apakah sebaiknya penambangan yang mereka geluti dilarang dan ditindak tegas. Meski demikian, para penambang berharap agar kondisi saat ini tetap dipertahankan ketimbang opsi pembatasan. Studi ini menyimpulkan bahwa ada jebakan politik kebijakan yang tidak konsisten atas kebijakan penambangan timah pada level implementasinya dan diperkuat oleh lemahnya budaya hukum di tengah-tengah masyarakat.
\end{abstract}

Kata kunci: penambang ; politik kebijakan; penambangan timah

\section{Introduction}

In his writing titled Het Kamerlid Van Bekernstein op reis door Indie (published around the 1880's), M.F.H Perelaer stated that tin melting has been practiced by Bangka natives since the 10th century, 
marking the beginning of the tin journey in the archipelago (Sujitno 2007:10-11, Heidhues 2009, Ibrahim et al. 2018). The establishment of tin mining around 1733 required a great amount of miners, dominated by the Chinese, in order to fulfill the number needed on Bangka island (Purnama 2015:204). In this era, the miners' role became limited to that of blue-collar workers for Palembang Kingdom, VOC, the Dutch colony, and Japanese colonialism. In the independence era, mining activities gradually decreased, due to the decline of mine production overall. In the new order era, a mining centralization policy was applied through Law Number (No) 11 of 1967. Tin as a strategic mining commodity has lead to public limited access to tin mining, marking the beginning of the state's monopoly of tin.

In the new order era, the public and local government acts as the audience for tin exploitation in their region. The license for tin mining was only granted to PT. Timah Tbk as a state-owned enterprise and to PT. Kobatin as a private multinational cooperation. Mining operations were also under the surveillance of military protection. During this period, many Bangka people were jailed for mining and storing tin, even if it only weighed one kilogram. People also illegally brought tin out of Bangka (Erman 2010:78).

The state monopoly officially ended after the issuance of the Ministerial Regulation by the Ministry of Trade and Industry in 1998, which stated that tin was no longer prohibited concerning export activities. Tin stopped being regarded as a strategic commodity and the public could also freely mine it. Public mining started mushrooming, and this became known as non-conventional mining (Tambang Inkonvensional, hereafter referred to as TI).

TI miners originated in the PT. Timah regulation era, which considered self-operated mining areas as no longer being beneficial. After the Indonesian reformation, TI miners started to mine outside the jurisdiction of PT. Timah, which involved thousands of miners in the entire Bangka Belitung area. There was no exact number kept of the miners because the activities were performed spontaneously and sporadically.

In 2006, according to the People's Tin Mining Association (Asosiasi Tambang Timah Rakyat, hereafter referred to as ASTIRA), there were 13,345 unregistered TIs. When added to the unregistered ones, this number could reach 18,000 units in total (Susilo \& Maemunah 2009:43). The Mining and Energy Department in the Central Bangka Regency recorded that up until 2011, unlicensed mining (Pertambangan Tanpa Izin, hereafter referred to as PETI) totaled 1,363 mines (Bangkapos 2009). If 6 regencies/cities on average have the same amount of PETI, then there were at least 9,541 PETIrelated activities ongoing in Bangka Belitung province. According to the Main Chief of Pt. Timah tbk, until March 2012, there were 6,230 unconventional miner units in Bangka Belitung waters. The Indonesian Forum for the Environment (Wahana Lingkungan Hidup Indoesia, hereafter referred to as WALHI) in Bangka Belitung recorded that since 2004 and up until 2013, there were 81,000 TI units, 54 private smelters and over 1,000 tin mining licenses (WALHI Babel 2013).

Most miners in land or water areas, whose status was unregistered, were in a disadvantaged position. Their interest was simply to earn a living to meet their daily needs, given the minimum option of occupation available to them and their limited skills when it came to choosing job. As a matter of fact, people with various occupations, such as fishermen and farmers, also often shift their profession to being a miner because it is a quicker way of generating income. The People's Mining Area Policy (Kebijakan Wilayah Tambang Rakyat, hereafter referred to as WPR) and the People's Mining License (Izin Pertambangan Rakyat, hereafter referred to as IPR), which could legalize their status, is still far from being implemented. Illegal miners are thus exposed to the risk of violating laws on environmental degradation, not to mention the threat of occupational accidents. Milieudefensia (2016) identified the problem of safety in mining areas in their report on responsible mining that stated that illegal miners faced a high level of risk in their daily life due to the absence of health and safety insurance at work. On the other hand, their work greatly contributed to tin production, which was exported by smelters and utilized by global electronic industries (List of Smelters and Refiners BlackBerry 2013, Friends of the Earth 2012, Ibrahim et al. 2018). 
This research study focused on the perception of the non-conventional miners concerning their work. There are three basic ideas aims to uncover the miners' knowledge of their context, behavior, and expectations. This study analyzed the political circumstances of the mining policy that had an impact on the knowledge, behavior, and expectations of the miners in the practical sphere of mining activities.

\section{Research Method}

This research applied a qualitative research method. The method aimed to grasp the complete image of the mining reality experienced by the miners. The research population was the Bangka Belitung people working as miners in 7 regencies/cities, specifically those who were non-conventional miners. Since there is no exact number of miners, the researchers applied non-probability sampling with a quota sampling technique to generate the data. From each regency, theresearchers choose 15 miners. Therefore, there were 105 respondents in total, originating from 7 regencies/city in Bangka Belitung Province.

The researchers arranged a question list, to be answered using a Likert scale, focusing on 3 main questions including the miners' context, behavior, and expectations of mining activities. Knowledge of the context in this article is described as knowledge of the situation that is not visually apparent, but that is experienced by the public. Expectation is described as the miners' wishes when they face a certain situation. The researchers applied a frequency table and Kendall's Tau-b correlation result assisted by SPSS program version 20 as the analysis technique tool.

\section{Results and Discussion}

\section{Description of the Miners}

The description of the miners included a brief explanation on the personal identification of the miners such as age, sex, citizen status, education background, duration of mining, and income from mining. Such a description is essential to learning the miners' character, which forms their perception and knowledge of the context, their behavior, and future expectations of their job.

Most of the miners were aged 39-48 years old (38.3\%). In general, the miners were in the productive age range, which is from 29 up to 58 years old. The young miners aged 19-28 years old made up $3.7 \%$. 38.3\% of those aged 39-48 years old were identified as being the head of the household. Miners aged from 19-28 made up 3.7\%. Even though this number is low compared to the miners in the higher age range, it is apparent that this group started working in mining right after finishing high school or college. There were also other kids involved in mining activities, even though this was unrecorded by this survey.

$87 \%$ of miners were male, indicated that male is the sex that dominates this occupation. However, the remaining $13 \%$ was made up of women who work in the mining area. Female involvement in this field proves that they are trying to support and fulfill their household needs even though through it is blue-collar work.

For the residential status question, $93 \%$ of the respondents were local residents. In other words, the mining activities were performed by local residents or migrants that had been living in the area for a long time. Only $7 \%$ of them identified as migrants. However, in TI cases, the number of people who had emigrated was quite high. Rachman (2008:227) stated that in general, TI workers frequently originate from South Sumatera, Jambi, Lampung, and Java.

$44 \%$ of the respondents had graduated from elementary school. Miners who were equipped only with a primary level of education worked as miners because it is an easy way to generate an income. $20 \%$ had graduated from junior high school and $22 \%$ had graduated from senior high school. In general, the data showed that the educational background of the miners was the main reason why people chose to work in this sector. Miners who graduated from elementary school and junior high school were lacking in skills, particularly for job vacancies that require at least a senior high school degree. 
For the mining duration question, $21 \%$ of miners had been working for over 12 years; $17.8 \%$ had been working for $9.1-12$ years; $15,1 \%$ had been working for 3,1-6 years and $19,6 \%$ had been working for 1-3 years. Most of the respondents were miners who had been working for a long time in the mining sector. Only $13.1 \%$ admitted that they had just started work as a miner. Mining is still an attractive occupation for local people or for immigrants, which indicates the high dependency of the Bangka people on mining activities.

For income level, 63\% stated that they gained 1-3 million rupiah monthly from mining. Only 7\% admitted that they received over 5 million in a month. Compared to the Provincial Minimum Wage, this amount is adequate enough to fulfill the miner's monthly spending, which has become the main attraction of mining.

The general description of the Bangka Belitung miners displays the general character of the tin miners. Firstly, the miners are dominantly in their productive age. Secondly, male is the majority sex, even though there are a number of female miners. Thirdly, most of the miners are only equipped with a primary level of education. Fourth, the miners that have been mining for a long period indicate people's dependence on the activity. Lastly, mining provides a relatively high income to fulfill the miners' daily needs. The data was analyzed with the SPSS statistics program and Kendall Tau-b correlation test with the results (see Table 1).

Table 1.

Kendall Tau- $b$ test result

\begin{tabular}{lcccc}
\hline \multirow{2}{*}{$\begin{array}{c}\text { Individual } \\
\text { Characteristic }\end{array}$} & \multicolumn{2}{c}{ Perception of knowledge } & \multicolumn{2}{c}{ Perception of behavior } \\
\cline { 2 - 5 } & $\begin{array}{c}\text { Correlation } \\
\text { Coefficient }\end{array}$ & Sig. (2tailed) & $\begin{array}{c}\text { Correlation } \\
\text { Coefficient }\end{array}$ & Sig. (2tailed) \\
\hline Age & 0.000 & 1.000 & -0.138 & 0.068 \\
Sex & -0.098 & 0.246 & -0.143 & 0.083 \\
Residency & -0.013 & 0.876 & 0.057 & 0.490 \\
Education & -0.080 & 0.304 & 0.093 & 0.225 \\
Mining Period & -0.087 & 0.245 & -0.085 & 0.243 \\
Income & -0.227 & 0.060 & -0.179 & 0.081 \\
\hline
\end{tabular}

Source: Analyzed from the primary data

Based on Table 1, the Kendal tau-b correlation, we measure the miners individual characteristics using indicators related to age, sex, residency, education, mining period, and monthly income related to their knowledge and behavior, and whether they want to stick with their current occupation or not. The result was $p$ value Sig.(2-tailed) $>$ alpha $(0,05=5 \%)$, which means that there is no correlation between age, sex, residency, education, mining period, and monthly income with the miners' knowledge and behavior. The miners' perception scale is explained in the Table 2.

Based on Table 2, the miners' knowledge is of a moderate level. They answered the proposed questions neutrally. The same pattern occurred in behavior, with the miners showing neutrality in expressing their thoughts. If one day the government prohibits mining, then the miners will need to seek an alternative way to generate income.

\section{Knowledge of context}

Knowledge of context aims to uncover the perception of the tin miners regarding several important issues related to or regarding the consequences of their mining activities. Detailed answers to the questions related to the miners' perceptions of TI miners (see Table 3).

Based on Table 3,57\% of the respondents agreed whilst $23 \%$ strongly agreed, revealing that the majority of IT miners were aware and realized that their activities violate the law. They realized that mining should be done with legal permission according to the regulations. For the miners who 
admitted that they did not know that mining should be based on legal permission, this indicates a lack of information or that they received false information, such as public miners requiring no permission to mine or only big companies needing permission. Miners usually sell their mining products to licensed companies. Therefore, there is a strong need to confirm misinformation and wrong perceptions in the public through socialization in at the village level. The government also needs to reform the bureaucracy for the public, to better administer permission to mine. A lot of miners actually understand that they need to register with the government to get permission, but because the procedure is complicated, they continue mining illegally (Haryadi 2015). Rahayu (2012), in her research on TI miner law culture, revealed that the majority of miners were not aware of the necessity of registration and bureaucracy because of their low educational background and the time consuming process to get permission. This is more so given that they only stay in one place temporarily and move when the tin has ceased to be productive.

Table 2.

Score

\begin{tabular}{cccc}
\hline Variable & Score & Criterion & Perception \\
\hline Knowledge & $60 \%$ & Moderate & Neutral \\
Behavior & $42.5 \%$ & Moderate & Neutral \\
\hline \multicolumn{3}{c}{ Source: Analyzed from primary data }
\end{tabular}

Regarding the profit from tin mining, Table 3 describes that 56\% agree while $32 \%$ strongly agree. This means that almost $90 \%$ of miners realize that their monthly income is lower than that of a tin businessman. Businessmen buy tin from miners at a low price and sell it without reclamation costs, work safety insurance expenses and corporate social responsibilities.

Despite the miners' awareness of the law violations and their low income compared to that of the tin businessmen, $60 \%$ of miners agreed and $22 \%$ strongly agreed that mining activities are harmful to the environment. Only $4 \%$ stated that mining is environmentally safe. One miner was not able to determine that mining activities are harmful for the environment and even for the miners themselves. Yet, because they mine illegally, the miners are not obligated to reclamation, and the mining activity itself is conducted across a spread area sporadically (Yuarsah et al. 2017, Febriyanto et al. 2015, Nurtjahya et al. 2016, Putra et al. 2017, Siringoringo et al. 2014, Muslih et al. 2014).

Table 3.

Percentage of the knowledge of context

\begin{tabular}{|c|c|c|c|c|c|}
\hline \multirow[b]{2}{*}{ Questions } & \multicolumn{5}{|c|}{ Percentage of Answer (\%) } \\
\hline & $\begin{array}{l}\text { Strongly } \\
\text { Agree }\end{array}$ & Agree & Neutral & Disagree & $\begin{array}{l}\text { Strongly } \\
\text { disagree }\end{array}$ \\
\hline Aware of TI prohibition & 23 & 57 & 10 & 8 & 2 \\
\hline $\begin{array}{l}\text { Aware that miners' income is lower than } \\
\text { people who work in the tin industry }\end{array}$ & 32 & 56 & 6 & 6 & 0 \\
\hline $\begin{array}{l}\text { Aware that mining activities cause } \\
\text { environmental deterioration }\end{array}$ & 22 & 60 & 14 & 4 & 0 \\
\hline Aware of the risk of accidents & 31 & 48 & 6 & 12 & 3 \\
\hline
\end{tabular}

TI activities clearly do not apply occupational safety and health standards as regulated by law. Field workers in the mining sector are exposed to a greater risk of accidents. Responding to this issue, as explained in Table 3, 48\% of miners agreed and 31\% strongly agreed with the possibility of risk on a daily basis. Only 3\% of the miners stated that they had never experienced an accident in the workplace. Occupational accidents have long been the main threat to miners, causing injuries, disability, and even death (Haryadi 2012). The main reason that miners stay in their occupation is because they are left with a limited choice when it comes to earning an income. The situation re-ignites the urge to establish an applicable and ideal public mining model to secure the miner's occupational safety and health (Weinberg et al. 2017). 


\section{Miner's behavior}

The miner's behavior is an intriguing issue to observe, especially given the rising rejection rate from the public influence on mining activities.

Table 4.

Percentage of the miner's behavior

\begin{tabular}{lccccc}
\hline \multicolumn{1}{c}{ Questions } & $\begin{array}{c}\text { Strongly } \\
\text { Agree }\end{array}$ & Agree & Neutral & Disagree & $\begin{array}{c}\text { Strongly } \\
\text { disagree }\end{array}$ \\
\hline $\begin{array}{l}\text { Keep on mining even though it is forbidden } \\
\text { Cannot work in any other sector other }\end{array}$ & 26 & 54 & 11 & 8 & 1 \\
than in mining & 16 & 22 & 12 & 43 & 7 \\
$\begin{array}{l}\text { Requested to give money } \\
\text { Guarded in mining }\end{array}$ & 16 & 18 & 15 & 45 & 6 \\
Feel safe and comfortable in mining & 2 & 22 & 22 & 42 & 2 \\
$\begin{array}{l}\text { Tin business causing future environmental } \\
\text { problems }\end{array}$ & 11 & 45 & 21 & 11 & 12 \\
$\begin{array}{l}\text { TI should be closed } \\
\text { If TI is forbidden, then they are not sure } \\
\text { that they will get another job }\end{array}$ & 10 & 53 & 17 & 12 & 1 \\
\hline
\end{tabular}

Source: Analyzed from the primary data

The miner's perception regarding their mining activities indicates their readiness to work in other sectors if the tin mine is closed. Based on Picture 4, 54\% of miners agreed and $26 \%$ strongly agreed, which indicates that the miners are aware that their activities are forbidden. However, they stay in the mining sector to fulfill their daily needs, as an additional income, and for other varying reasons. $11 \%$ of them answered neutral which means that they actually have the desire to quit mining, but they still have no other occupation to turn to. In addition, no assertive measure by officers becomes the underlying reason for the miners to stick with the mining activity, whether as a main income or an additional one. Based on Table 4, 43\% claimed that they cannot additionally work in another sector. However, $22 \%$ and $16 \%$ answered agree and strongly agree respectively, which expresses their inability to find another job outside of the mining sector. The answer shows an intriguing pattern, in that the number of miners who are ready to look for another job and those who are not is almost equal.

The involvement of support from unidentified parties in illegal mining activities is hard to uncover. From the survey, at least $18 \%$ of miners agreed and $16 \%$ strongly agreed that there are parties requesting a mining fee. Even though the number for respondents who agreed $(45 \%$, whilst $6 \%$ strongly disagreed) is not as high as the group that expressed disagreement, the qualitative interviews found there to be an indication of agreement. $42 \%$ agreed and $16 \%$ strongly disagreed that in mining, they are not supported by a superior power or government. However, $22 \%$ and $2 \%$ of miners respectively answered that they are supported by clearly identified parties or the elites. It is important to note that this study only covered small-scale miners, not tin land-lords or tin collectors. This situation allows us to draw on the relationship between the elites who are often portrayed as tin landlords and the tin collector supporters who employ small-scale miners.

Based on Table 4, $45 \%$ of miners agreed and $11 \%$ strongly agreed that their current mining activities are convenient. Only $12 \%$ expressed inconvenience. The ease of generating income, supported by weak law enforcement, increased the miner's comfort. In many cases, an occupation shift from another sector to mining is inevitable because mining offers instant results (Adegboye 2012). However, in the midst of convenience, $17 \%$ agreed and $18 \%$ strongly agreed that mining will cause future environmental deterioration. Only $12 \%$ of miners disagreed that mining is potentially harmful 
to the environment. $40 \%$ of miners expressed disagreement and $12 \%$ strongly disagreed. In other words, even though they showed less domination, the miners reject the idea of the TI being shut down. This perception is related to the limited educational background of the miners, the difficulties involved in shifting their job due to job availability, and the inconvenience that they may experience. However, $25 \%$ of miners said that they can accept TI closure and that they are ready to seek for another occupation.

Related to the next behavior observed, $34 \%$ of miners disagreed with the possibility of finding another occupation while $10 \%$ strongly disagreed. This reveals that the miners, in general, are not certain if they can find another occupation outside of the mining sector. Underlying the assumption, most of the miners only graduated from elementary school and are therefore equipped with limited skill. 30\% of miners agreed with the possibility of finding another job. The percentage of those who agreed and disagreed with TI closure was almost even.

\section{Miners' expectations}

An expectation is a wish and an idealized situation that people try to accomplish, or it is a desired solution to solving a problem in the future. This study not only aimed to describe the existing knowledge and the miner's behavior, but the researcher also wished to learn of the miner's expectations of the future of mining activities.

Table 5.

\begin{tabular}{cc}
\multicolumn{2}{c}{ Priority policy proposal } \\
\hline Alternative & Percentage (\%) \\
123 & 22 \\
132 & 10 \\
213 & 19 \\
231 & 11 \\
312 & 28 \\
321 & 9 \\
\hline Source: Analyzed from the primary data
\end{tabular}

Based on Table 5, the policies proposed are listed as the following: 1) regulation re-arrangement; 2) law enforcement and 3) environmental situation improvement. The most popular option is proposal number five, which proposes prioritizing the management of the environmental impact. Highlighting environmental issues can be explained by the miners being aware that their daily activity is deteriorating the environment. Moreover, proposing reformations concerning the regulation of the sector would not be possible, since they do not have an adequate amount of information on the policies, thus the matter of legality is not a priority.

Table 6.

Expectation

\begin{tabular}{cc}
\hline Alternative & Percentage (\%) \\
Status Quo & 59 \\
Limitation & 41 \\
\hline Source: Analyzed from the primary data
\end{tabular}

The miners' future expectations about the tin mining industry explained whether the status quo should be preserved or whether there is an urge to implement limitations in relation to the ongoing mining activities. As shown in Table 6, those in favor of preserving the status quo were 59\%, which indicates that the miners favor the current condition. Only $41 \%$ preferred there to be limitations. Based on the data, this shows that dependency is the main feature that makes the miners wish to prolong the current mining situation, even though the level of this is not significant. 


\section{Policy Trap in Tin Mining Politics}

The results of the survey show that the miners are hesitant about the TI work that they engage in. On one hand, they are aware that their activities are prohibited by law, that they are deteriorating the environment, and that it only gives them a minimum level of income compared to people who work in the supply and production chain of the same industry. Stuck in this dilemma, mining is still their most prominent option, even though they realize that their activities create public controversy. It is interesting to learn that there are a large number of miners who are ready to change their occupation if one day mining is entirely prohibited. However, the number is not quite significant enough to conclude that they are ready to seek another occupation immediately. In other words, miners are open to possibly seeking another source of income if there is strict law enforcement in place to combat illegal tin mining.

Another interesting fact is that $52 \%$ of the respondents expressed their disagreement of tin mining potentially being prohibited. The data shows that the miners' aspirations are divided between those who support and those who oppose mining no longer being an option.

Ibrahim et al (2017) found that the situation is preserved by the prevailing policies in place. The government could actually enforce the law to minimize the negative effects of illegal mining. However, the data shows that there are gaps in the system that neglect illegal mining. Thus, we can agree that the situation provides a trap in relation to tin mining policies. The act of doing nothing to enforce the law is considered to be a government policy, even though public resistance is not as massive as we envisage.

Government officials have been applying double standards when handling cases of illegal mining. It cannot be overlooked that the government has been consistently informing the public of illegal mining and its consequences. However, the government also realizes that tin mining is able to meet people's daily needs. We envisage that there will be massive resistance if one day IT is completely prohibited. In the end, tin mining policy becomes less relevant due to the prevailing government actions that choose to remain silent when handling the issue.

This political and economic design is part of the tin mining policy that leads to public confusion. It is widely believed that concerning legal protection and occupation safety, the miners' position is not secure and remains risky. At the same time, there is the growing view in the public sphere that blames the miners for the ongoing environmental deterioration due to their mining activities. Political decision-making in relation to the status quo has formed the prevailing economic structure (Yustika 2009:1). In addition, Lane \& Ersson (1994:250) consider that economic variables are highly influenced by political decisions. At the practical level, inconsistency in policy implementation places the miners in a dilemma. This situation is supported by negligence, perpetuates the supply chain of the tin industry, continues the environmental deterioration problems, and the miners' benefits are still marginalized.

\section{Conclusion}

At the contextual level, the miners are aware that their activity is violating the law, deteriorating the environment, generating a low income compared to that of tin businessmen, and exposing them to a high risk of occupational accidents. However, the miners choose to continue their activities in the tin mining sector. Generally, they are not firm in their decision, and yet they hesitate to support tin mining prohibition. Half of the miners are firm that they can find other job outside of the tin mining sector. In fact, the voice of those who oppose mining prohibitions is not significant.

This study drew the conclusion that there are circumstances where the miners are stuck between the tin mining policies that allow them to keep mining, and the risks. The government and officials appear to preserve the status quo and ignore illegal mining, letting the problem of environment deterioration go uncontrolled. Even though the option to limit or prohibit illegal mining activity is available, the tin mining policy remains static. Tin mining policy creates an economic structure that perpetuates a double standard policy, thus the current situation is preserved. 


\section{References}

Adegboye MA (2012) Effect of mining on farming in Jos South Local Government Area of Plateau State. Journal of Soil Science and Environmental Management 3 (4):77-83.

Erman E (2010) Aktor, akses, dan politik lingkungan di pertambangan timah Bangka. Jurnal Masyarakat Indonesia Edisi XXXVI/No.20/2010.

Friends of Earth (2012) Mining for Smartphones: The True the Tin. www.foe.co.uk.makeitbetter.

Febriyanto A, Baskoro MS, Simbolon D, Haluan J, \& Mustaruddin (2015) The impact of tin mining on squid (Uroteuthis Chinensis) fishing ground in South Bangka. International Journal of Science: Basic and Applied Research (IJSBAR) 23 (1): 283-293.

Haryadi D (2012) Timah Pencabut Nyawa. Bangkapos, 4 Mei 2012.

Haryadi D (2015) Faktor kriminogen illegal mining timah di Bangka Belitung. Jurnal MasalahMasalah Hukum 44 (1).

Heidhues MFS (2008) Bangka Tin and Mentok Pepper, Chinese People Role in 18th to 20th Century Bangka Island Development. Jakarta: Yayasan Nabil.

Ibrahim, Haryadi D, \& Wahyudin N (2017) Tin and authority contestation: Government, people, and businessmen in chronical tin management. Proceedings of 135th The IIER International Conference, Kyoto, Japan, 7th-8th November 2017.

Ibrahim, Haryadi D, \& Wahyudin N (2018) From charm to sorrow: The dark portrait of tin mining in Bangka Belitung, Indonesia. PEOPLE: International Journal of Social Sciences 4 (1):360382.

Lane JE \& Ersson S (1994) Ekonomi Politik Komparatif. Diterjemahkan oleh Haris Munandar. Jakarta: PT. Raja Grafindo Perkasa.

List of Smelters and Refiners BlackBerry, Updated November 15, 2013

Milieudefensie (2016) Responsible Mining: Tin, Goodelectronics. Amsterdam.

Nurtjahya E, Franklin J, \& Agustina F (2017) The Impact of tin mining in Bangka Belitung and its reclamation studies. MATEC Web of Conferences, 101:04010.

Muslih K, Adiwilaga EM, \& Adiwibowo S (2014) Habitat characteristic and menduk river fresh water fish affected from tin mining in Bangka Regency. AKUATIK-Fishery Resources Journal 8 (2):17-23.

Purnama A (2015) Sejarah Pertambangan Timah dan Keberadaan Etnis China di Pulau Bangka. In: Buku Kelekak Sejarah Bangka. Dinas Kebudayaan dan Pariwisata Bangka, Bangka Belitung.

Putra, HF, Sulistijorini, \& NS Aryanti (2017) Landscape Function of Post Tin-Mining Land After Reclamation in Bangka, Indonesia. IOP Conf. Series: Earth and Environmental Science 58 (2017) 012018.

Rachman R (2008) Plus Minus Tambang Inkonvensional dalam Buku Rusli Rachman Beginilah adanya. Yogyakarta: Aksarasastra.

Rahayu DP (2012) Budaya hukum penambang Timah Inkonvensional (TI) terhadap mekanisme perizinan berdasarkan perda pengelolaan pertambangan umum di Provinsi Kepulauan Bangka Belitung. Jurnal Masalah-Masalah Hukum 41 (4).

Siringoringo MR \& Hadi TA (2014) The condition of coral reefs in West Bangka water. Journal Mar. Res. Indonesia 39 (2): 63-71. 
Sujitno S (2007) Dampak Kehadiran Timah Indonesia Sepanjang Sejarah. Jakarta: Cempaka Publishing.

Susilo J \& Maemunah S (2002) Tiga Abad Melayani (Potret Tambang Timah di Bangka Belitung). Jakarta: JATAM.

Yuarsah I, Handayani EP, \& Rakhmiati, \& Yatmin (2017) Restoration of soil physical and chemical properties of abandoned tin mining in Bangka Belitung Islands. J Trop Soils 22 (1): 21-28. 